\title{
Immunological Heterogeneity of Superoxide Dismutases in the Acholeplasmataceae
}

\author{
GABRIEL Y. LEE AND GEORGE E. KENNY* \\ Department of Pathobiology SC-38, University of Washington, School of Public Health and Community Medicine, Seattle, \\ Washington 98195
}

\begin{abstract}
The superoxide dismutases from Acholeplasma laidlawii and Acholeplasma hippikon were serologically related, whereas the superoxide dismutase from Acholeplasma equifetale appeared to be unique serologically. Enzymes from Acholeplasma granularum and Acholeplasma axanthum did not show any serological reactivity. Moreover, the acholeplasmic enzymes exhibited electrophoretic heterogeneity, indicating the evolutionary diversity of superoxide dismutases.
\end{abstract}

Acholeplasma laidlawii was the first member of the Mycoplasmatales shown to exhibit superoxide dismutase activity (9). Kirby et al. (5) reported the presence of superoxide dismutase in A. laidlawii but not in Mycoplasma pneumoniae. To study the occurrence and serological properties of superoxide dismutase in Mycoplasma and Acholeplasma species, we examined cell lysates from 13 different species belonging to the genera Mycoplasma, Acholeplasma, and Ureaplasma for both enzymatic and antigenic activities.

A total of 13 Mycoplasmatales species were studied (Table 1). The distribution of the species was as follows: 7 species in the genus Mycoplasma, which represented five different serological groups of species (3); 5 species in the genus Acholeplasma; and 1 serotype in the genus Ureaplasma. The antigens, immunogens, and antisera were prepared as described elsewhere (4).

To detect the occurrence of superoxide dismutase activity in the various organisms, cell lysates were electrophoresed in agarose (10) and then stained for enzyme activity. Rocket and two-dimensional immunoelectrophoresis were performed as described elsewhere (4). After electrophoresis, the slides were soaked in $10 \mathrm{mM}$ potassium phosphate buffer (pH 7.5) for $1 \mathrm{~h}$ at room temperature and then immersed in the enzyme-staining solution for enzyme identification and localization. The positive activity stain for superoxide dismutase described by Misra and Fridovich (7) was used to localize enzyme activity. The staining solution contained 2 $\mathrm{mM}$ dianisidine and $0.1 \mathrm{mM}$ riboflavin in $10 \mathrm{mM}$ potassium phosphate buffer at $\mathrm{pH}$ 7.5. After electrophoresis, the slides were equilibrated in $10 \mathrm{mM}$ potassium buffer $(\mathrm{pH} 7.5)$ for $1 \mathrm{~h}$, immersed in the staining solution for $1 \mathrm{~h}$ at room temperature, rinsed briefly with distilled water, and illuminated by fluorescent light for about $15 \mathrm{~min}$ in an aluminum foil-lined box. Zones containing superoxide dismutase developed brown spots or peaks. After color development was complete, the slides were washed in distilled water overnight and then dried in an incubator for photography. Peroxidase was detected by immersing the slides in a solution containing 2 $\mathrm{mM}$ dianisidine and $10 \mathrm{mM}$ potassium phosphate buffer $(\mathrm{pH}$ 7.5) for $1 \mathrm{~h}$, followed by a 15 -min soaking in $0.1 \mathrm{mM} \mathrm{H}_{2} \mathrm{O}_{2}$.

Superoxide dismutase activity was not detected in the seven Mycoplasma species examined or in Ureaplasma urealyticum. On the other hand, enzyme activity was detected in all five Acholeplasma species studied (Table 1). Bovine superoxide dismutase (Sigma Chemical Co., St. Louis, Mo.) was tested in parallel as a positive control for enzyme

* Corresponding author. staining and was used as a standard for comparing the electrophoretic mobilities of the enzymes from the various species. The superoxide dismutases from the five Acholeplasma species exhibited quite different electrophoretic mobilities (Fig. 1), ranging from 0.94 to 2.2 (with the mobility of bovine superoxide dismutase defined as 1.0 ).

The enzyme-staining system used in this study also detected the presence of peroxidase, but color development was much slower (7). To be certain that the staining was due to superoxide dismutase and not to peroxidase, the electrophoresed cell lysates were stained for peroxidases. Horseradish peroxidase (Sigma) was tested in parallel as a positive control for the staining reaction. None of the Acholeplasma species exhibited any peroxidase activity. Moreover, incorporation of $10 \mathrm{mM}$ potassium cyanide in the staining solution for superoxide dismutase did not inhibit the formation of the stained product (peroxidase activity is suppressed by $10 \mathrm{mM}$ cyanide [7]), indicating that the enzyme activity detected was indeed superoxide dismutase.

The electrophoretic mobilities of Triton X-100-solubilized cell lysates of the various Acholeplasma species were compared with the mobility of bovine superoxide dismutase in agarose containing $0.1 \%$ sodium deoxycholate and $0.5 \%$ Triton X-100 (charge shift conditions [2]). No changes in electrophoretic mobilities were observed, suggesting that the superoxide dismutases from the various Acholeplasma species were hydrophilic and likely cytoplasmic (2).

Triton X-100-solubilized cell lysates of the various species were tested against their homologous antisera in rocket immunoelectrophoresis and then stained for superoxide dismutase activity. Only the enzymes from Acholeplasma equifetale, Acholeplasma hippikon, and A. laidlawii formed specific immunoprecipitin peaks with their respective antisera (Table 2). In addition, other preparations of antisera made against Acholeplasma axanthum and Acholeplasma granularum also failed to recognize the superoxide dismutases from these two organisms. Two-dimensional immunoelectropherograms of the various Acholeplasma species with their respective homologous antisera were stained for superoxide dismutase activity (Fig. 2). Again, only the enzymes from $A$. equifetale, A. hippikon, and $A$. laidlawii formed stainable enzyme-antibody complexes.

To determine whether the superoxide dismutases from $A$. equifetale, $A$. hippikon, and A. laidlawii showed crossreactivity, cell lysates of the different organisms were tested against heterologous antisera in rocket immunoelectrophoresis (Table 2). The enzymes from $A$. hippikon and $A$. laidlawii showed strong reactivity to antisera to these two organisms, 
TABLE 1. Occurrence of superoxide dismutases in the Mycoplasmatales

\begin{tabular}{|c|c|c|c|c|c|}
\hline Organism & Strain & Source & $\begin{array}{l}\text { Serol- } \\
\text { ogical } \\
\text { group }^{a}\end{array}$ & $\begin{array}{c}\text { Super- } \\
\text { oxide } \\
\text { dismutase } \\
\text { activity }^{b}\end{array}$ & $\begin{array}{c}\text { Rela- } \\
\text { tive } \\
\text { mo- } \\
\text { bility }\end{array}$ \\
\hline Bovine group 7 & $\mathrm{~N}-29 \mathrm{~B}$ & J. Tully & 1 & - & \\
\hline A. axanthum & $\mathrm{S}-743^{\mathrm{T} d}$ & J. Tully & 2 & + & 1.0 \\
\hline A. equifetale & $29724^{\mathrm{T}}$ & $\mathrm{ATCC}^{e}$ & 2 & + & 2.2 \\
\hline A. granularum & Friend & J. Tully & 2 & + & 1.9 \\
\hline A. hippikon & $29725^{\mathrm{T}}$ & ATCC & 2 & + & 1.0 \\
\hline A. laidlawii & 14192 & ATCC & 2 & + & 1.3 \\
\hline $\begin{array}{l}\text { Mycoplasma } \\
\text { gallisepticum }\end{array}$ & 15302 & ATCC & 4 & - & \\
\hline $\begin{array}{l}\text { Mycoplasma } \\
\text { pneumoniae }\end{array}$ & AP-3546 & G. Kenny & 5 & - & \\
\hline $\begin{array}{l}\text { Mycoplasma pul- } \\
\text { monis }\end{array}$ & 63 & G. Kenny & 6 & - & \\
\hline $\begin{array}{l}\text { Mycoplasma ar- } \\
\text { ginini }\end{array}$ & $\mathrm{G}-230^{\mathrm{T}}$ & M. Barile & 7 & - & \\
\hline $\begin{array}{l}\text { Mycoplasma gal- } \\
\text { linarum }\end{array}$ & 15319 & ATCC & 7 & - & \\
\hline $\begin{array}{l}\text { Mycoplasma } \\
\text { hominis }\end{array}$ & 14027 & ATCC & 7 & - & \\
\hline U. urealyticum & Type 8 & M. Shepard & & - & \\
\hline
\end{tabular}

${ }^{a}$ As defined by Kenny (3).

${ }^{b}+$, Enzyme activity; - , no enzyme activity.

c Mobility relative to that of bovine superoxide dismutase, which was defined as 1.0 .

${ }^{d} \mathrm{~T}=$ Type strain.

${ }^{e}$ ATCC, American Type Culture Collection.

suggesting that the superoxide dismutases from these two species are closely related serologically. Antiserum to $A$. equifetale formed a very faintly stained immunoprecipitin peak with the enzyme from $A$. hippikon, but no peak with the enzyme from the other heterologous species. Again, no immunoprecipitin peaks were formed with the enzymes from $A$. axanthum and $A$. granularum when they were tested against heterologous antisera.

To rule out the possibility that the enzyme activity was due to medium contaminants, $10 \mu \mathrm{l}$ of yeast extract-soy peptone dialysate broth and $10 \mu \mathrm{l}$ of agamma horse serum were similarly tested and stained for superoxide dismutase

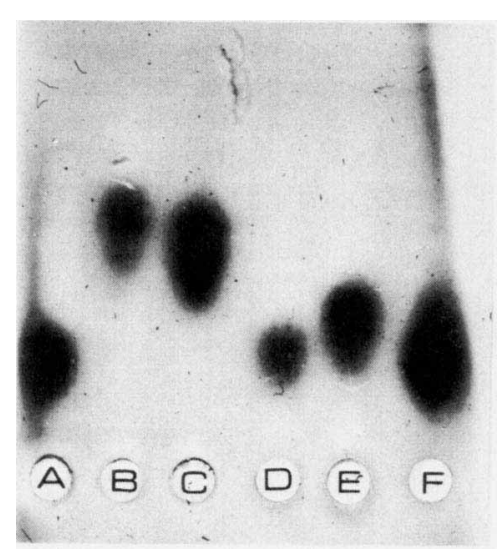

FIG. 1. Agarose electropherograms of the superoxide dismutases of A. axanthum (lane A), A. equifetale (lane B), A. granularum (lane C), A. hippikon (lane D), and A. laidlawii (lane E) and of bovine superoxide dismutase (lane F). Triton X-100-solubilized cell lysates were electrophoresed for $1 \mathrm{~h}$ at $6 \mathrm{~V} / \mathrm{pcm}$ and stained for enzyme activity as described in the text.
TABLE 2. Serological properties of the acholeplasmic superoxide dismutases $^{a}$

\begin{tabular}{lcccccc}
\hline & \multicolumn{5}{c}{ Antiserum } \\
\cline { 2 - 6 } \multicolumn{1}{c}{ Antigen } & $\begin{array}{c}\text { A. axan- } \\
\text { thum }\end{array}$ & $\begin{array}{c}\text { A. equi- } \\
\text { fetale }\end{array}$ & $\begin{array}{c}\text { A. granu- } \\
\text { larum }\end{array}$ & $\begin{array}{c}\text { A. hip- } \\
\text { pikon }\end{array}$ & $\begin{array}{c}\text { A. laid- } \\
\text { lawii }\end{array}$ \\
\hline A. axanthum & - & - & - & - & - \\
A. equifetale & - & + & - & - & - \\
A. granularum & - & - & - & - & - \\
A. hippikon & - & \pm & - & + & + \\
A. laidlawii & - & - & - & + & + \\
Bovine superoxide & - & - & - & - & - \\
$\quad$ dismutase & & & & & \\
\hline
\end{tabular}

${ }^{a}-$, No precipitin peak stained for enzyme; + , strong staining of precipitin; \pm , weak staining.

activity. No detectable enzyme activity was observed; therefore, the enzyme activity detected with the cell lysates was acholeplasmic. The fact that no enzyme activity was detected in any of the Mycoplasma species grown in the same horse serum lot also ruled out medium component contamination (3). Furthermore, the differences in the electrophoretic mobilities and serological specificities of the acholeplasmic enzymes also indicate specificity.

We detected superoxide dismutase in the Acholeplasma species tested but not in the Mycoplasma species studied, which corroborated the findings of other investigators $(5,6$, 8) and extended the number of species examined for this enzyme to 7 in the genus Acholeplasma, 17 in the genus Mycoplasma, and one serotype in the genus Ureaplasma. Since the Mycoplasma species chosen were representative of most serotaxonomic groups of the genus Mycoplasma (3), it appears unlikely that superoxide dismutase is present in the genus Mycoplasma.

The enzyme in $A$. equifetale is quite specific, showing only weak cross-reaction with $A$. hippikon. The superoxide dismutases from $A$. laidlawii and $A$. hippikon have a common specificity, whereas the superoxide dismutases from $A$. granularum and $A$. axanthum did not exhibit any antigenic activity when they were tested against homologous antisera or heterologous antisera. The lack of serological crossreactivity and the heterogeneous electrophoretic mobilities of the acholeplasmic superoxide dismutases indicate the

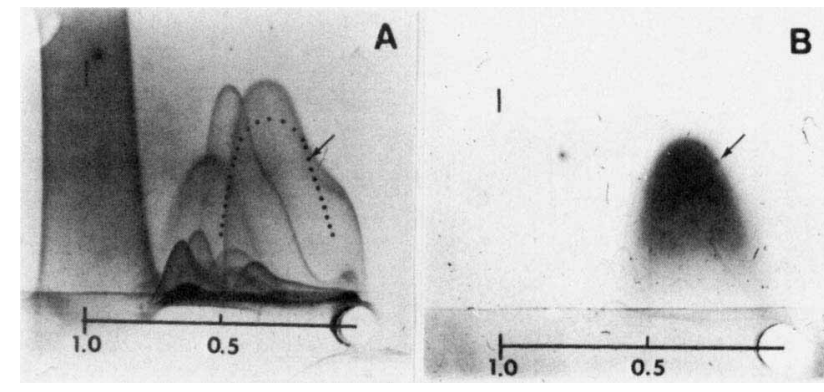

FIG. 2. Detection of superoxide dismutase in antigenic profiles. (A) A. laidlawii tested against homologous antiserum, Coomassie Blue stain. (B) A. laidlawii tested against homologous antiserum, stained for superoxide dismutase activity. The scales at the bottom indicate the relative mobilities of the peaks; 1.0 equals the mobility of bovine albumin, the peak of which is identified by the vertical bar at the top of the slide. The anode was to the left and top. The arrow indicates the superoxide dismutase peak, and the dotted curve indicates the relative position of superoxide dismutase in the Coomassie blue-stained profile. 
evolutionary diversity of this enzyme. Similar antigenic and electrophoretic diversity has been reported in Streptococcus and in other microorganisms (1). The Mycoplasmatales also show a large degree of antigenic variation in their adenosine triphosphatases and reduced nicotinamide adenine dinucleotide dehydrogenases (10).

This study was supported in part by Public Health Service grant AI-06720 from the National Institute of Allergy and Infectious Diseases.

\section{LITERATURE CITED}

1. Britton, L., D. Malinowski, and I. Fridovich. 1978. Superoxide dismutase and oxygen metabolism in Streptococcus faecalis and comparisons with other organisms. J. Bacteriol. 134:229-236.

2. Helenius, A., and K. Simmons. 1977. Charge shift electrophoresis: method for distinguishing between amphilic and hydrophilic proteins in detergent solution. Proc. Natl. Acad. Sci. U.S.A. 74:529-532.

3. Kenny, G. E. 1979. Antigenic determinants, p. 351-384. In M. F. Barile and S. Razin (ed.), The mycoplasmas, vol. 1. Cell biology, Academic Press, Inc., New York.

4. Kenny, G. E. 1983. Agar precipitin and immunoelectrophoretic methods for detection of mycoplasmic antigens, p. 441-456. In
S. Razin and J. G. Tully (ed.), Methods in mycoplasmology, vol. 1. Mycoplasma characterization. Academic Press, Inc., New York.

5. Kirby, T., J. Blum, I. Kahane, and I. Fridovich. 1980. Distinguishing between Mn-containing and Fe-containing superoxide dismutases in crude extracts of cells. Arch. Biochem. Biophys. 201:551-555.

6. Lynch, R. E., and B. C. Cole. 1980. Mycoplasma pneumoniae: a prokaryote which consumes oxygen and generates superoxide but which lacks superoxide dismutase. Biochem. Biophys. Res. Commun. 96:98-105.

7. Misra, H. P., and I. Fridovich. 1977. Superoxide dismutase and peroxidase: a positive activity stain applicable to polyacrylamide gel electropherograms. Arch. Biochem. Biophys. 183:511-515.

8. O'Brien, S. J., J. M. Simonson, M. W. Grabowski, and M. F. Barile. 1981. Analysis of multiple isoenzyme expression among twenty-two species of Mycoplasma and Acholeplasma. J. Bacteriol. 146:222-232.

9. Petkau, A., and W. S. Chelack. 1974. Protection of Acholeplasma laidlawii $\mathrm{B}$ by superoxide dismutase. Int. J. Radiat. Biol. 26:421-426.

10. Sjostrom, K. E., and G. E. Kenny. 1983. Distinctive antigenic specificities of adenosine triphosphatases and nicotinamide adenine dinucleotide dehydrogenases as means for classification of the order Mycoplasmatales. Int. J. Syst. Bacteriol. 33:218-228. 